УДК $811.161 .2 ’ 373.2$

\title{
АКТУАЛІЗАЦІЯ ПРЕЦЕДЕНТНОСТІ В ПУБЛЩИСТИЦІ ІВАНА БАГРЯНОГО
}

\author{
Жанна Колоїз
}
Криворізький державний педагогічний університет
Kryvyi Rih State Pedagogical University пр. Гагаріна, 54, Кривий Ріг, 50086, Украӥна
koloiz.zv@gmail.com

Колоїз Ж. Актуалізація прецедентності в публіцистиці Івана Багряного

У статті досліджено прецедентні феномени, які маніфестують певну культурно значущу інформацію в мові публіцистики Івана Багряного. Зосереджено увагу на тому, що публіцистичний доробок письменника активізує когнітивну базу через актуалізацію інтертекстуальності й прецедентності, грунтований на використанні різних прецедентних феноменів, що виступають яскравими маркерами й вербальними сенсорними стимулами. 3'ясовано функційно-прагматичну наснаженість прецедентних феноменів. Репрезентовано передовсім такі функції прецедентних феноменів, як-от: номінативно-інформативна, персуазивна, аксіологічна, прагматична, парольноідентифікаційна, людична, експресивно-декоративна тощо.

Ключові слова: прецедентний феномен, прецедентність, функція, публіцистика. Багряного

Колоиз Ж. Актуализация прецедентности в публицистике Ивана

В статье исследуются прецедентные феномены, манифестирующие ту или иную культурно значимую информацию в языке публицистики Ивана Багряного. Акцентируется внимание на том, что публицистическое наследие писателя активизирует когнитивную базу через актуализацию интертекстуальности и прецедентности, основанное на использовании различных прецедентных феноменов, выступающих яркими маркерами и вербальными сенсорными стимулами. Анализируется функциональнопрагматическая насыщенность прецедентных феноменов. Репрезентируются прежде всего такие функции прецедентных феноменов, как: номинативноинформативная, персуазивная, аксиологическая, прагматическая, парольноидентификационная, людическая, экспрессивно-декоративная и т. д.

Ключевые слова: прецедентный феномен, прецедентность, функция, публицистика. 
Koloiz Zh. Precedence actualization in the journalism of Ivan Bagrianyi

This article investigates precedence phenomena, which manifest different culturally significant information in the journalism language of Ivan Bagrianyi. The paper focuses on the fact that the writer's journalistic works activate the cognitive basis through the intertextuality and precedence. Author's journalism is based on the use of various precedent phenomena, which are stated as the bright markers and verbal sensory stimuli. Precedence phenomena are defined as the results of certain cognitive operations, specifically "packed" knowledge, serving as a means of encoding, transforming and interpreting relevant information. Their use within the proposed communication activates evokes the reader's attention and encourages for appropriate logical operations that contribute to the correct decoding of the reduced content.

It also states that the writer applies graphic (quotation marks, ellipsis) and text (various comments preceded by represented text samples) precedence markers. Above mentioned marking is traced the example of headlines. It is determined that the citation of so called "foreign texts" has not only a pragmatic orientation, but also demonstrates the peculiarities of the linguistic personality, his aims, motives, intentions, and linguistic-cultural orientation. Due to these facts one can speak about the author's belonging to the corresponding national community. This article also shows that the author uses mainly well-known, actively repeated intertextual samples, which form the basis for the further text production. They belong to the group of units with a high precedence degree.

Moreover this paper reveals functional and pragmatic inspiration of precedent phenomena. The following features of precedent phenomena are represented, such as nominative-informative, persuasive, axiological, pragmatic, passive-identification, human, expressive-decorative, etc. The list of such functions is unlimited. In addition, one and the same sample illustrates the implementation of a number of functions, although, undoubtedly, one of them should be considered as the dominant one.

Key words: precedent phenomenon, precedence, function, journalism.

Постановка проблеми та її зв'язок із важливими науковими завданнями. Визначальним напрямком вітчизняної лінгвостилістики $\epsilon$ дослідження мовотворчості видатних культурних діячів, що, репрезентуючи самобутнє мовомислення українського народу, водночас демонстрували власні мовностилістичні пріоритети, оригінальні мовні засоби, використовувані й задля реалізації комунікативно-прагматичної мети. Особливу ж увагу в цьому аспекті привертають творчі індивідуальності 3 різнобічними літературно-мистецькими вподобаннями. Однією 3 таких непересічних постатей в українському мовно-літературному просторі можна справедливо вважати Івана Багряного - яскравого представника 
антирадянської ідеології, “мужнього патріота”, “чесного письменника", для якого “художнє слово i, передовсім, публіцистика стали засобом боротьби за національну гідність і волю свого народу, за державну незалежність України" [Bahrianyi / Багряний 2006 : 4]. Письменницькі публіцистичні тексти, які спрямовані на викриття й засудження тоталітарної сталінської репресивної системи, російського великодержавного шовінізму й у яких “яскраво відбилася його подвижницька політична та організаторська діяльність в еміграції” [Bahrianyi / Багряний 2006 : 4], мають посісти належне місце в історії сучасної українській літератури загалом й літературної мови зокрема.

Говорити про те, що на сьогодні творча спадщина Івана Багряного є повністю вивченою й об'єктивно оціненою, очевидно, було б великим перебільшенням, хоч би тому, що і творчість, і сама постать митця порівняно нещодавно з'явилися в науковому обігові, лише в кінці минулого століття були долучені до материкового мовно-літературного простору.

У такому разі актуально звучатимуть питання і стосовно семантичної та прагматичної природи лінгвальних одиниць у контексті як індивідуально-авторської, так і національномовної картини світу, і щодо тих чи тих культурно маркованих знаків як репрезентантів етнічної свідомості відповідної лінгвоспільноти, і стосовно окреслення лінгвального простору духовного коду тощо.

Аналіз останніх досліджень та публікацій. Після того, коли творчий доробок письменника знайшов свого читача, він відразу ж став об'єктом зацікавлення науковців, передовсім літературознавців (М. Балаклицький, С. Беспутна, М. Васьків, Ю. Войчишин, О. Головій, В. Гришко, О. Дашко, А. Желновач, М. Жулинський, Г. Клочек, С. Кобута, О. Ковальчук, Г. Костюк, Ю. Лавріненко, В. Мартинець, В. Наддніпрянець, Д. Нитченко, Л. Пазенко, О. Пастушенко, В. Працьовитий, I. Романова, Б. Романенчук, М. Сподарець, О. Тарнавський, Л. Череватенко, О. Шапошникова, О. Шугай та ін.). Зауважимо, до дослідження тих чи тих аспектів художніх текстів письменника неодноразово апелювали й мовознавці (М. Братусь, І. Гайдаєнко, В. Калашник, 
О. Кардащук, Т. Коць, О. Кульбабська, О. Лавер, Л. Марчук, Б. Плющ, С. Привалова, Н. Сологуб, М. Філон, А. Ярова та ін.). I як результат - низка монографічних і дисертаційних праць, покликаних маніфестувати роль письменника і в історії сучасної української літератури, і в історії сучасної української літературної мови.

Авторська ж публіцистика, що, так би мовити, з'явилася у “вільному доступі" значно пізніше, також потребувала належного поцінування з боку і літературознавців (І. Дзюба, C. Кравченко, I. Михайлин, О. Подобєд, Н. Шаповаленко, А. Шаргородська), і мовознавців (Т. Демкова, А. Коваленко). А відтак - цілком закономірною можна вважати і появу дисертаційної праці О. Клєщової "Мова публіцистики Івана Багряного” (2003), у якій проаналізовано стилістичні функції різних шарів лексики та стилістичне використання фразеологізмів, колоративів, власних назв, індивідуальноавторських новотворів у їх зв'язку зі світобаченням письменника, виокремлено максимально естетично наповнені мовні одиниці - образ України та лексико-семантичне поле CРСР тощо [Klieshchova / Клєщова 2003].

Примітним $\epsilon$ те, що письменницька публіцистика маніфестує оригінальні, незаангажовані, “вільні від ідеологічного тиску” зразки об'єктивного аналізу тогочасних історичних подій. Осмислення актуальних явищ i важливих питань радянського післявоєнного суспільно-політичного життя зазвичай грунтується на актуалізації прецедентності й використанні прецедентних феноменів.

До вивчення прецедентних феноменів [Krasnyih / Красных 1997 : 62-75] і суміжних із ними, зокрема інтертекстуальних, явищ [Denisova / Денисова 2003] неодноразово зверталися як вітчизняні, так зарубіжні дослідники, оприлюднюючи результати своїх наукових розвідок у статтях, дисертаційних і монографічних працях (Д. Багаєва, С. Банникова, А. Берестова,
Н. Бирюкова,
О. Боярських,
О. Ворожцова, Д. Гудков, Ю. Гунько, Г. Зав’ялова, І. Захаренко, О. Земська, М. Ілюшкіна, Ю. Караулов, Т. Космеда, В. Красних, Н. Кузьміна, С. Кушнерук, Л. Мардієва, Л. Меркотан, О. Нахімова, 
Н. Немирова, Н. Піддубна, О. Селіванова, О. Семенець, А. Свиридова, Ю. Сорокін, Г. Слишкін та ін.) [див. також: Slyishkin / Слышкин 2000; Slyishkin / Слышкин 20041.

Мета запропонованої статті - дослідження функційнопрагматичної наснаженості прецедентних феноменів у мові публіцистики Івана Багряного.

Виклад основного матеріалу. Сучасні дослідники прецедентності кваліфікують іï як феноменальну здатність ядерних елементів культурного простору репрезентувати ментальність національно-лінгвокультурної спільноти як результат знань та уявлень носіїв певної мови різних поколінь. Звідси, відповідно, поява й обгрунтування ключового поняття теорії прецедентності - прецедентний феномен. Щоправда, донині науковці по-різному потрактовують i саме терміносполучення, i “набір основоположних властивостей прецедентних феноменів (унікальність, відтворюваність, упізнаваність, зрозумілість і т. ін.), і принципи їх типології” [Koloiz / Колоїз 2017 : 142-143].

Не викликає принципових заперечень твердження науковців про те, що прецедентні феномени здебільшого добре відомі значній частині представників національної лінгвоспільноти, $є$ актуальними в когнітивному плані, демонструють зразки когнітивної обробки дійсності, транслюють культурну пам'ять, унаочнюють фундаментальні ціннісні орієнтації національної лінгвокультури, актуалізують культурно значущу для неї інформацію, постійно поновлювану у процесі спілкування.

У різних наукових студіях осмислюються різні диференційні ознаки, що дає змогу уналежнювати той чи той феномен до категорії прецедентних. Ідеться передовсім про такі ïх особливості, як-от: здатність виконувати роль еталонів культури, “культурних скрепів”, які поєднують окремі культурні пласти й історичні епохи в єдину систему [Grishaeva / Гришаева 2004 : 15].

Прецедентні феномени є результатом певних когнітивних операцій, певним чином “упакованими” знаннями, що слугують засобом кодування, трансформації й інтерпретації відповідної 
інформації, можуть функціонувати у вигляді згорнутих метафор, засвідчувати як раціональну, так і емоційну оцінку, отримувати символічне значення і т. ін. Наприклад: Скорше біблійний цар Ірод може навернутись до християнства, як його наступник ХХ століття. Сталін зробив з релігії знаряддя своїх політичних махінацій і тільки. А релігія як була викорінювана в СССР, так $i$ буде викорінювана (1, с. 30). У проілюстрованому контексті об'єднані дві поняттєві сфери: міфологічний емотивно наснажений прецедентний феномен (цар Ірод) дає змогу структурувати нову концептуальну сферу, уявити іï через інтертекстуальні зв'язки (Сталін-наступник ияаря Ірода ХХ століття).

Інший приклад: Коли робітники, одягнуті в матроські бушлати, здумали заявляти про свою волю, - Ленін вирішив поставити кронштадтців на коліна залізом і кров'ю. Сталін зробив те саме - він вирішив поставити робітництво на коліна перед комуністичною ідеєю й перед ленінською партією, перед ленінським мавзолеєм, пустивши в рух ленінський державний апарат насильства, тюрму, каторгу, радянський “Шемякин cyd” (1, с. 495) і т. ін. Уконтекстовані прецедентні імена та висловлення добре відомі широкому колу носіїв української (і не тільки!) культури, здебільшого впізнавані без додаткових коментарів, акумулюють інформацію й маніфестують відповідні знання у стислій формі, приміром, “Шемякин суд” - актуалізує відомості, маніфестовані у старовинній російській сатиричній повісті, що викривала свавілля й корисливість феодального суду, зокрема князя Дмитра Шемяка, який відзначився своєю жорстокістю, підступністю й несправедливістю. Атрибутивний поширювач радянський (“Шемякин суд”) ускладнює природу прецедентного феномена, який, відновлюючись у конкретній ситуації спілкування, передає цінну культурну інформацію, отримує здатність бути реінтерпретованим. У результаті створення вторинного тексту через ускладнення первинного, розширення його меж, уведення до загального культурноісторичного простору. Зауважимо: особливістю публіцистичних текстів Івана Багряного $є$ те, що так звані “ядерні елементи культурного простору” злокалізовані в контексті радянського соціуму, відображають національні культурні традиції 
у сприйнятті й оцінюванні реальних подій, реальних осіб і реального часу (Сталін, Ленін, СССР).

3 іншого боку, автор апелює i до тих "культурних скрепів”, які отримують схвальну оцінку національної лінгвоспільноти, демонструють символічне значення, як-от: Це політична свобода $і$ забезпеченість від насильства і терору. Словом, ие отой лад “без хлопа і пана”, про який віщував ще великий Шевченко, ота “своя хата”, а в ній “своя” украӥнська народна "правда" - щчо сьогодні становить собою суть української народної національної ідеї. Це ж становить і основу нашого політичного кредо (1, с. 84). Використання прецедентних феноменів сприяє декодуванню згорнутого, редукованого змісту. Сприйняття запропонованої національно значущої інформації відбувається крізь призму асоціацій, пов'язаних 3 конкретною історичною особою (Шевченко) та текстами його творів (пор.: В своїй хаті своя правда, I сила, $i$ воля (“ І мертвим, і живим, і ненародженим...”). Такі знаки перебувають у центрі культурного простору, навантажені культурно значущою інформацією, а когнітивне тло є спільним для адресанта та мільйонів адресатів, належних до українськомовної національної спільноти. У кожному разі механізми сприйняття, усвідомлення, розуміння й інтерпретації того чи того культурного знака грунтовані на фонових знаннях, культурних традиціях, емоціях і т. ін. носіїв мови. Пор. також: Той же пам'ятник, справжній пам'ятник, на якого заслужив великий Син украӥнського народу і про який заповів він у своєму “Заповіті”, ще чекає свого воздвигнення. I тим пам'ятником можуть бути не гори чужої глини й ріки липкого зрадливого єлею, не брили холодного граніту й мертвотної чужої бронзи, а вогонь свободи, тріумф розкованої начії, воля отих усіх “малих рабів німих” - словом, здійснення нарешті великої ідеї великого Пророка - “своя (украӥнська) хата” й “своя (українська) правда” в ній (1, с. 577). Прецедентні феномени на зразок проілюстрованих зберігаються в когнітивній базі української лінгвоспілноти у вигляді “національно детермінованих інваріантів сприйняття “культурних предметів" [Gudkov / Гудков 2003 : 98]. Частина прецедентних одиниць демонструє 
виразну маркованість, що пов'язується насамперед із використанням лапок (“малих рабів німих”) і так званим квазіцитуванням (від лат. quasi - “немов, майже”), коли відтворювані частини чужого тексту зумисне модифікуються (“своя (украӥнська) хата” й “своя (українська) правда”).

Публіцистика Івана Багряного, грунтована великою мірою на прецедентності й інтертекстуальності, не лише актуалізує відповідну інформацію про тогочасні факти передусім “радянської” дійсності, а й маніфестує нові знання, сприяє освоєнню соціалістичної (жахливої!) реальності й пізнанню світу, пов'язаного 3 побудовою комуністичного суспільства. Наприклад: Я не хочу вертатись на ту “родіну”. Нас тут сотні тисяч тих, що не хочуть вертатись. Нас беруть 3 застосуванням зброї, але ми чинимо скажений опір, ми воліємо вмерти тут, на чужині, але не вертатись на ту “родіну”. Я беру це слово в лапки, як слово, наповнене для нас страшним змістом, як слово чуже, з таким незрівнянним иинізмом нав'язуване нам радянською пропагандою. Більшовики зробили для 100 національностей єдину “совітську родіну” $і$ нав'язують iї силою, ияю страшну тюрму народів, звану СССР (1, с. 22).

Прецедентні феномени, уконтекстовані у структуру статті “Чому я не хочу вертатись до СССР?” (і не тільки!), отримали суспільний резонанс, викликають негативну індивідуальноавторську оцінку й оцінку прогресивної національно свідомої української спільноти, для якої та “родіна”, “совітська родіна”, звана Союзом Радянських Соціалістичних Республік (рос. Союзом Советских Социалистических Республик, скорочено $(C(P)$, ніколи не була і не буде країною, що їі українці зазвичай називають Батьківщиною, або Вітчизною, не була і не буде рідним, батьківським краєм, до якого відчувають сакральне почуття любові, поєднане 3 патріотизмом. Метафорично “совітську родіну" з середини XIX століття іменовано як тюрму народів, за І. Багряним, - страшну тюрму народів, що уособлює в'язницю 3 великою кількістю бранців, які перебуваючи в ній, зазнають усіляких утисків і гноблення. За такого підходу до структурування й осмислення актуальної інформації автор повсякчас послуговується як графічними, так і 
текстовими маркерами прецедентності: 3 одного боку, вдається до використання лапок, на чому робить акцент, 3 іншого, супроводжує репрезентовані зразки (імена, висловлення) різноманітними коментарями, які прямо або опосередковано вказують на авторство, джерело і т. ін. Наприклад, викладові матеріалу, уміщеному під заголовком "Чад імперії" (1, с. 112-115), передує два епіграфи: перший - "Картагена мусить бути зруйнована” - відсилає читача до латинського крилатого висловлення (Carthago delenda est), що означає наполегливий заклик до боротьби 3 ворогом; другий А программа наша вот какова. Чтобы мы, мерзавцьь, говорили, а прочие чтобы молчали. Чтобы наши, мерзавцев, затеи $и$ предложения принимались немедленно, а прочих желания чтобь оставались без рассмотрения. Чтобы нам, мерзавиам, жить было повадно, а прочим чтоб ни дна ни покрышки не было. Чтобы нас, мерзавцев, содержали в холе и неженьи, а прочих всех - в кандалах. Чтобы нам, марзавцам, сделанный вред за пользу считался, а всем прочим, если бы и польза была принесена, то такова за вред бы считалась - $є$ цитатою М. Салтикова-Щедріна, яка в подальшому отримує відповідні коментарі. Графічний маркер вказує на іншотекстовість, текстовий - виступає засобом паспортизації (повної або часткової) прецедентного тексту, попереджує про можливі комунікативні збої, пов'язані 3 наявністю лакун у фонових знаннях адресата [Semenets / Семенец $2004: 131$ ].

Окрім того, на нашу думку, говорити про якусь уніфікацію, стандартизацію подачі тих чи тих зразків прецедентності було б великим перебільшенням. Пор., приміром, заголовкові назви, що актуалізують прецедентні феномени: Так тримати!! (1, с. 82); Фарватер n'ятої колони (1, с. 175); Мементо морі (1, с. 231); Партія “останніх могікан” (1, с. 327); Чуєш, брате мій, товаришу мій!.. (1, с. 346); Лицарі абсурду (1, с. 377); Камо грядеш? (1, с. 383); За щастя треба боротись (1, с. 432); Між Сціллою і Харібдою (1, с. 439); Танець живота (1, с. 469); “Розбрід і паніка”? (1, с. 471); Юпітере, ти злостишся... (1, с. 544); Коли гримлять литаври $i$ б'ють барабани (1, с. 657); Чи крок назад, чи крок вперед? (1, с. 663); 
На щуастя, на здоров'я, на Новий рік! (1, с. 684); Хвилювання в “сторозтерзаному Києві” (1, с. 695); Коса на камінь (1, с. 713); В краплі води (1, с. 724); Дешевим коштом (1, с. 729); Сдність протилежностей $(1$, с. 738); Геркулесові стовпи... (1, с. 772); Гіркі, дітки, заробітки! (1, с. 778); Троянський кінь (1, с. 801). Зауважимо: адресант послуговується так званим графічним маркуванням не лише у вигляді лапок, а й трьох крапок. Прецедентна одиниця, “закодована” у структурі заголовка, зазвичай отримує необхідні коментарі під час представлення відповідної інформації. Наприклад: ДИВИСь У КОРІНЬ! Цей девіз ніби став банальністю від частого вживання з легкої руки дотепного Кузьми Пруткова, проте він не втрачає від того ані слушності, ані своєї актуальності й нині. <..> Ну як тут не сказати перестороги словами Кузьми Пруткова: "Дивись у корінь”! (1, с. 745); “ОТАМ-ТО МИЛОСТИВІЇ МИ НЕНАГОДОВАНУ І ГОЛУ ЗАСТУКАЛИ СЕРДЕШНУ ВОЛЮ..." Чи можна сказати краще про подї в Угорщині, ніж оцими б Шевченковими словами?! < ..> Події в Угорщині $\epsilon$ підтвердженням ганебної суті клишоногого й садистичного старшобратнього імперіалізму, так здемаскованого Шевченком, вони ж $\epsilon$ й яскравим актом здійснення його пророцтва про те, що той імперіалізм чекає в майбутньому (1, с. 535); НЕ ХЛІБОМ САМИМ... Нi, ми тут не про Дудінцева, що, б'ючись над проблемою узмістовлення людського життя, написав книгу під цим заголовком, позичивши його $з$ святого письма. Хоч, кажучи правду, сам цей Дудінщев з його книгою може бути яскравим доказом саме того, як не треба робити пропаганди, бо в пошуках великої ідеї для людини, яка б (ідея) наповнила людську душу величним змістом, не знайшов нічого ліпшого, як дав призначення людині виробляти каналізаційні рури і освятив иче високим свангельським девізом - “не хлібом самим...” (1, с. 776). Більшість так званих інтертекстем $є$ стереотипними, так би мовити, готовими знаками, що вирізняються принциповою нерелевантністю авторства (інформація про нього $є$ надлишковою, а то й несуттєвою), як-от: МЕМЕНТО МОРІ (Пам'ятай про смерть) (пор.: лат. Memento mori). Без сумніву, ось цุе грізне 
попередження, зроджуючись з подій у Східній Свропі, змусило московських диктаторів сьогодні прищулити вуха від страху й відібрало у них мову (1, с. 518).

Покликання на, так би мовити, “чужі тексти” має як прагматичну скерованість, демонструє насамперед особливості мовної особистості, іiі мету, мотиви, інтенції, так і лінгвокультурну, згідно з якою можна говорити про належність автора до відповідної національної спільноти. У багатьох випадках актуалізується прецедентність, грунтована не лише на прецедентних іменах і висловленнях, а й на прецедентних текстах і прецедентних ситуаціях, як-от: Світ мусить знати, щзо Кох із кохенятами прийшов як гідний спадкоємець $i$, перебравши ключі від тюрьми, лише змінив вивіску. Ще до приходу гестапо було енкаведе, ще до гітлерівського голоду був сталінський голод, особливо в - 1933 роиі - спецголод, коли вимерло кілька мільйонів украӥнського населення страшною смертю; що до гестапівського терору був сталінський терор, коли мільйони пішли на каторгу, а сотні тисяч замордованих виповнили могили по Вінницях <..> щзо до гітлерівської політики винищення украӥнського народу була така сама сталінська політика, що московський червоний фашизм приготував трунт для приходу й панування кохів $i$ вони користувались тими самими тюрмами. А знаючи цее, світ мусить знати, щя й тепер, після розгрому Гітлера з усіма його кохами для українського народу ситуація лишилась та сама. Усі, хто був у гітлерівських таборах примусової прачі, опинилися в таборах радянської каторги; народ, що трепетав під безперервним терором, трепече під ним і тепер, потерпає в тяжких злиднях, безправ' $і$, під вічною загрозою голоду й шибениці, в тяжких шорах більшовицького тоталітаризму, позбавлений найелементарніших прав, а надто - національної $і$ людської свободи. А надто свободи судити ци карати свойх розпинателів, свойх окупантських “рейхскомісарів” $і$ тюремників (1, с. 173-174). Пор. : прецедентні імена Кох, Гітлер актуалізують інформацію про воєнні злочини періоду Другої світової війни. До того ж, як свідчать історичні джерела, Кох, призначений райхскомісаром України, прославився своєю жорстокістю, за що й був названий 
“другим Сталіним”: як і Сталін, вважав Україну не національним, а територіальним утворенням. Звідси, відповідно, і паралелізм представлення національно значущої інформації (гестапо - енкаведе; гітлерівський голод - сталінський голод (спеиголод 1933 року); гестапівський терор - сталінський терор; гітлерівська політика винищення українського народу сталінська політика винищення украйнського народу тощо). Наразі можна говорити про взаємодію різних зразків прецедентних феноменів, зокрема прецедентних імен, прецедентних висловлень і прецедентних ситуацій. Пор. також: Щодо Хрущуова, то щее пара слів: якщчо увесь світ розуміє, щчо гра изього вождя КПРС - ие прагнення до одноособової диктатури $і$ якраз сталінського типу, то чому треба нам передчасно цюю думку ревізувати, не давщи ій пройти історичну перевірку? Нам ие $i$ не вигідно, $i$ не потрібно. Нехай нас не введуть в оману хрущовські кивиморги в бік Украйни. Ленін $i$ Сталін моргали в цей бік ще й не так, але щзо з того вийшло, ми дуже добре знаємо (1, с. 556). У такий спосіб, удаючись до використання прецедентних ситуацій, прецедентних імен і т. ін., публіцист прагне інформувати світ про особливості життя соціалістичного соціуму, ретранслює масовому адресату справжню сутність комуністичних керманичів, сутність комуністичної ідеології, пов'язаної 3 утвердженням певних життєвих цінностей (лжецінностей!) та агітацією на їх підтримку.

Більшість прецедентних феноменів (прецедентних текстів, прецедентних ситуацій, прецедентних імен), використовуваних письменником, виконують номінативно-інформативну функцію - називають відтворювані й пізнавані людською свідомістю ті чи ті реалії об'єктивної дійсності й водночас передають інформацію про ціннісні пріоритети лінгвокультурної спільноти. Наприклад: Спустошень, яких завдасть цей “закон” українському народові знову, не виміряти нічим. Як не виміряти жертв, що їх завдав свого часу навіть такий “невинний” закон, як той, що увійшов у історію московських масакр під назвою: “За колоски”(1, с. 586), де закон “За колоски”, або закон “Про n'ять колосків", - народна назва репресивного радянського 
закону часів Голодомору, власноруч написаного Сталіним, згідно з яким було засуджено десятки тисяч українців. Подібні прецедентні феномени маркують інтенції адресанта, репрезентують ідеологічну специфіку епохи. Інший приклад: Останні могікани прославленого російського <..> “демократичного соціалізму” різних татунків хотіли б себе якось зберегти, якою завгодно иүіною, хоч би й иіною осмішення себе перед історією, ціною скандального самозаперечення та перекреслення всього дотеперішнього свого “чистого", “непримиренного”, “непогрішимого” соціалістичного “вірую”. Звичайно, при всякій грі добрі грачі намагаються зберегти хорошу міну (1, с. 327). Трансформоване прецедентне висловлення (пор.: Зберегти хорошу міну при поганій грі) увиразнює зміст інформації, репрезентованої через прецедентні тексти ("Останній із могікан” - історичний роман Д. Купера),“Вірую” - символ віри, молитва "Вірую в єдиного Бога Отця, Вседержителя, творця неба і землі, і всього видимого і невидимого...”). Письменник використовує відповідні інтертекстеми 3 певною прагматичною метою, запропоновані читачеві інтертекстуальні знаки сприймаються і як прихований засіб вираження оцінки, і як засіб створення ігрового моменту, i як засіб демонстрації ерудиції, i як прийом переконання адресата та комунікативного впливу на нього, i як прийом експресивізації контексту, і як спосіб установлення контакту [Denisova / Денисова 2003 : 163-178].

Прецедентні тексти, будучи феноменами культури i цивілізації, загальновідомі, відтворювані, являють собою їх результат i підгрунтя подальшого продукування. Вони уналежнені до одиниць 3 високим ступенем прецедентності, отримують по кільканадцять і кількасот (а то й більше!) життів, оновлюють свою структуру та семантику i, відповідно, ціннісні характеристики. Наприклад: Експресія, метод і добір епітетів у цій писанині гідні саме органу комуністичних московських поплентачів, носіїв і адептів ідеології, яка має основну заповідь - “мета виправдовує засоби”. <..> Судячи з тієї оскаженілості, наша партія стала на передову лінію $і$ завдає багато клопоту комуністичним вельможам та їхнім шавкам. 
Це нас тішить, $і$ вся гавкотня тих шавок нас веселить. “Собаки брешуть - значить їдемо” (1, с. 175); “Ворон воронові ока не виклює”, - каже народна мудрість. Тож не виклюють собі ока $і$ ці всі “ворони”, бо вони ж зв'язані круговою порукою кров'ю народу $i$ мусять “колективно” правити і колективно брехати (1, с. 503-504); "Не тратьте, мовляв, - куме, сили - нас увесь світ боїться й коекзистує з нами, мармируйте ж так, як вам приказують вожді, соратники Леніна. Вони краще знають, в чім ваше щастя" (1, с. 658-659); А тим часом московський червоний “васька" слухає собі й нічого з того не робить - він собі жере, чи пак смачно глитає, за “мирнокоекзистенційним" столом" (1, с. 698) тощо. Подекуди такі мовно-культурні знаки слугують точкою відліку для розмірковування. До того ж, згідно 3 позицією дослідників, саме прецедентні феномени сприяють реалізації закону економії мовних засобів (номінативна функція), допомагають авторові оприлюднити свою позицію й переконати в іï правильності свого співбесідника (персуазивна функція), ілюструють лінгвокреативний потенціал, грунтований на мовній грі (людична функція), уможливлюють порозуміння (парольна функція) [Slyishkin / Слышкин 2000 : 85-104]. Цілком імовірно, що окреслені функції виявляються не ізольовано, а доповнюють одна одну. Аналізуючи конкретний прецедентний феномен, зазвичай говорять про різний ступінь актуалізації кожної $з$ них.

Актуалізована в той чи той спосіб номінативна, або номінативно-інформативна, прецедентність $-<\ldots>$ “геніальний” афоризм Сталіна про "жсіть стало лучше, жіть стало вєсєлєє” прикривав неуявні злидні, страхіття голоду й голизни та босоногості мільйонів “будівників комунізму” (1, с. 657) підтверджується передовсім доволі строкатим ономастичним прецедентним простором на зразок Соловки (радянське Дахау); Воркута; Бухенвальд; світ Трумена і Ненні, світ Етлі, де Голля $і$ Тореза; другий Будда чи Могомет; Ніагара; Сталін $і K^{\circ}$ і т. ін., зокрема й переосмисленим, модифікованим, як-от: Раз уже нас на неї вивело саме життя $і$ вручило нам скромну, але Богом благословенну Давидову пращу, щзоб змагатися з московським 
комуністичним голіафом, - ми ї̈ не випустимо з рук. Тим більше, щзо ми маємо наочний доказ, щуо наша пращуа б’є й разить ворога безпомилково (1, с. 546). В останньому контексті актуалізуються і прецедентні імена (Давид, Голіаф), і прецедентна ситуація, і прецедентний (біблійний) текст: автор апелює до старозаповітної оповіді про перемогу царя Давида над філістимлянським воїном Голіафом за допомогою пращі зброї для метання каміння, металевих куль.

Номінативно-інформативна функція прецедентних феноменів майже завжди супроводжується персуазивною, людичною чи парольною, або парольно-ідентифікаційною, що уможливлює демонстрацію належності комунікантів до тієї чи тієї (переважно однієі) спільноти. Такі одиниці зазвичай $є$ національно прецедентними, стосуються національного культурно-історичного простору, що досить часто взаємодіє, вконтекстований у чужоземний. Наприклад: Якщзо б Угорщчина була відокремленою землею, без жодних зв'язків із світом, а найперше - якби угорські героӥчні “раби малі" були відокремлені абсолютно неперехідними бар'єрами від усього радянського концтабору, тоді-може. А так з иієї боротьби встає примара якраз напророкованої великим Шевченком перспективи для душителів $i$ розпинателів, до якої, перспективи, вони котяться невблаганно, до приходу отого дня, коли: Розкуються незабаром Заковані люде... (1, с. 536). А звідси ясно, яка ж доля спіткала б Шевченка в добу зворушливої “диктатури пролетаріату”. Така сама, яка спіткала тисячі й тисячі української інтелігенції, українських письменників і митців, украӥнських учених $i$, нарешті, мільйони “рабів малих", щуо не схотіли або не вміли улягати брутальній волі насильників і ідейних шахраїв (1, с. 536). Пор.: Дія викликає протидію. I найважніший при масовім терорі внутрішній спротив мас, ставання тих мас в антагоністичну позицію супроти режсиму. За всіх циих умов наша боротьба буде виграна. Так чи так. Не прийде новий Петлюра, то прийде украйнський Timo... (1, с. 165), де, з одного боку, Петлюра, відомий як організатор українських повстанських збройних сил, з іншого, украӥнський Tiто - такий собі українець, можливо, і 
послідовник Петлюри, який, як і лідер Югославії, змоделює певну систему управління, що сприятиме збереженню єдності й незалежності української держави.

Ti чи ті різновиди прецедентних феноменів у публіцистичних текстах I. Багряного подекуди зменшують напруженість у спілкуванні, уможливлюють передавання неприємних або заборонених смислів за допомогою іносказання. Звідси, відповідно, можна говорити про реалізацію не просто людичної, а людично-евфемістичної функції, як-от: $A н і$ достославне “митьє й катанье”, ні достославний “пряник $\boldsymbol{i}$ батіз”, ні жодні партійні й комсомольські білети, виявляється, не можуть переробити людських душ, щуо люблять свою землю, свою історію, свій народ, щуо люблять свободу. Прометеӥв вогонь волелюбства, виявляється, невмирущчй $i$ непідвладний навіть найдикішим північним самодурам і фельдфебелям, як $і$ не підвладний ренегатам, льокаям “отечества чужого”; не підвладний багнетам иарським, не підвладний танкам та кулеметам “пролетарським” (1, с. 535); Який же й величавий розрахунок! Який же і гуманний метод в боротьбі проти тих, кого “родіна" “простила великодушно”! Чи ж ие не шедевр радянської людоловної моралі! Але не впадаймо від того в переляк. "Не дав Бог свині ріг”! Нічого нового. Це все те, про щзо ми знали, до чого були приготовані ц̆ про щзо, як про справжні наміри людоловів, давно говорили. Нічого нового (1, с. 539); Апетит, кажуть, приходить під час їди - саме тому малі поступки не тільки народних мас усіх республік СССР $і$ сателітів не заспокоїли, а навпаки - розгойдали надї, піднесли тиснення внутрішніх парів до вищої точки. Це, як бачимо, примусило Кремль вдатися до відновлення терору й усісї сталінщини в усій ї̈ красі й величі - щоби скувати кригою жаху тую “відлигу”, що почалася. Такий трагічний кінець “нового курсу”. Хоча цее не кінець, ие - ще не скінчений танець в зачарованому колі “хвіст витяг, ніс зав'яз”! (1, с. 540-541). Прецедентні феномени сприймаються як загальне тло, що сприяє увиразненню описуваних подій. І. Багряний говорить, так би мовити, натяками (“митьє й катанье”, “пряник $і$ батіг”, Не дав Бог свині ріг тощо), що мають викликати в адресата 
певну реакцію. А задля цього, цілком закономірно, останній повинен володіти необхідною сукупністю фонових знань. Інакше інформацію досить важко декодувати. Проілюстровані контекстуальні зразки маніфестують здебільшого різні семіотичні коди, вирізняються особливою інформативністю, інтертекстуальністю, прецедентністю i, відповідно, поліфункційністю.

У такому разі можна говорити ще й про аксіологічну, і про прагматичну, і про експресивно-декоративну функції [Berestova / Берестова 2016]. Наприклад: Що т. зв. “радянська влада” нас не любить - ие відомо. Що в боротьбі проти нас, як і проти всіх своїх супротивників, всемогутній і всевладний радянський Юпітер ніколи не визначався делікатністю й культурою, коли на нього находив сказ $і$ корчі люті, це теж відомо. Що він ніколи не ліз, як то кажуть, за словом (за брутальним словом, за похабною лайкою!) в кишеню - ие теж відомо. І все ж дивно чути, як останній час радянський Юпітер у своїй пресі та в радіопересиланнях визвірився на нас, і то якраз на нас, на 3-підрадянських емігрантів, недавніх радянських громадян, та на нашу вільну пресу. Дивно тому, що ие сталося на тлі солодких співів (яких же й солодких співів!) на тему “амністій”, “прощення всіх гріхів перед владою”, зазивання нас додому, на "родіну”, на тлі навального $і$ повсякчасного $i$ повсевсюдного демонстрування “любові” до нас, “пошани” до нашої людської гідності, “зрозуміння нашої трагедії” $i$ m. д., i m. n. I от раптом Юпітера прорвало. Юпітер не втримався в позі гуманіста й людинолюба і з-за цієї пози, з-за иієї машкари виперла нагло його справжня суть $i$ його справжне ставлення до нас, політичних емігрантів, та до нашого слова правди. Солодкий спів сирени заглушило крещендо Юпітерової люті й брутальної лайки. Перли, які посипалися з медоточивих уст Юпітера на зміну чаруючому співові сирени, направду подиву гідні. Особливо, коли взяти до уваги, щчо перед тим <..> він використовував навіть дітей, щуоби якнайпереконливіше зазивати нас додому та демонструвати нам свою великодушність; в нападі сказу, коли його раптом прорвало, він забув про свою делікатну тактику перед тим (1, с. 544). 
Прецедентні феномени, зокрема й взаємодіючи 3 іншими вербальними засобами увиразнення мовлення, вирізняються потужним комунікативно-прагматичним потенціалом, впливають на адресата, збуджуючи його емоції й уяву, активізуючи пам'ять, мислення й увагу.

Публіцистика Івана Багряного переконливо демонструє вміння іï автора писати правдиво, аргументовано, яскраво, переконливо й творчо. Використання розмаїття прецедентних феноменів (універсально прецедентних, національно прецедентних, соціумно прецедентних) свідчить про всебічну обізнаність письменника 3 національною та світовою культурою. Інакше кажучи, Іван Багряний належав до тих достойників, кого сьогодні називають універсалами. Він бачив зв'язки, суперечності між різними явищами, умів швидко схоплювати суть тих чи тих подій, апелював до так званого емоційного інтелекту читачів, виражав особисте ставлення до соціалістичної дійсності загалом і до тих чи тих ситуацій зокрема.

Висновки та перспективи подалыших наукових розвідок. Аксіоматично нині звучить твердження про те, що Іван Багряний - яскравий представник української діаспори залишив помітний слід у розбудові національної публіцистики. Функційна природа його публіцистичних текстів ще потребує скрупульозного й системного вивчення. Наразі ж зауважимо: публіцистичний доробок письменника активізує когнітивну базу через актуалізацію інтертекстуальності й прецедентності, грунтований на використанні різних прецедентних феноменів, що виступають яскравими маркерами й вербальними сенсорними стимулами.

Функційна представленість прецедентних феноменів у публіцистиці Івана Багряного доволі строката. Вони репрезентують передовсім такі функції, як-от: номінативноінформативна, персуазивна, аксіологічна, прагматична, парольно-ідентифікаційна, людична, експресивно-декоративна тощо. Перелік таких функцій не є вичерпним. Окрім того, один і той самий зразок ілюструє реалізацію низки функцій, хоч, безперечно, одну з них варто вважати домінантною. 


\section{Література}

1. Багряний І. Публіцистика : Доп., ст., памфлети, рефлексії, есе / Упоряд. О. Коновал ; Передм. І. Дзюби ; Післямова Г. Костюка. 2-е вид. Київ : Смолоскип, 2006. $856 \mathrm{c:}$

2. Берестова А. А. Релігійна прецедентність у мові української прози кінця XX - початку XXI століття : дис. ... канд. філол. наук : 10.02.01 / Харківський національний педагогічний університет імені Г. С. Сковороди. Харків, 2016. $212 \mathrm{c}$.

3. Гришаева Л. И. Прецедентные феномены как культурные скрепы (к типологии прецедентных феноменов). Феномен прецедентности $u$ преемственность культур / под общ. ред.: Л. И. Гришаевой, М.К.Поповой, В. Т. Титова. Воронеж : ВГУ, 2004. С. 15-46.

4. Гудков Д. Б. Теория и практика межкультурной коммуникации. Москва : ИТДГК “Гнозис", 2003. 288 с.

5. Денисова Г. В. В мире интертекста: язык, память, перевод. Москва : Азбуковник, 2003. 298 с.

6. Клєщова О. Є. Мова публіцистики Івана Багряного : автореф. дис. ... канд. філол. наук : 10.02.01. Київ, 2003. 23 с.

7. Колоїз Ж. В. Проект українського "Словника прецедентних феноменів". Філологічні студї : Науковий вісник Криворізького державного педагогічного університету. Кривий Ріг : ФОП Маринченко С. В., 2017. Вип. 16. С. 139-160.

8. Красных В. В., Гудков Д. Б., Захаренко И. В., Багаева Д. В. Когнитивная база и прецедентные феномены в системе других единиц и в коммуникации. Вестник Московского университета. Серия 9: Филология. 1997. № 3. C. $62-75$.

9. Семенец О. П. Прецедентный текст в языке газеты : дис. ... канд. филол. наук : 10.02.01 / Российский государственный педагогический университет им. А. И. Герцена. Санкт-Петербург, 2004. 225 с.

10. Слышкин Г. Г. Лингвокультурные концепты и метаконцепты: дис. ... д-ра филол. наук : 10.02.19 / Волгоградский государственный педагогический университет. Волгоград, 2004. 315 с.

11. Слышкин Г. Г. От текста к символу: лингвокультурные концепты прецедентных текстов в сознании и дискурсе. Москва : Академия, 2000. 128 с.

\section{References}

1. Bahrianyi I. Publitsystyka : Dop., st., pamflety, refleksii, ese / Uporiad. O. Konoval ; Peredm. I. Dziuby ; Pisliamova H. Kostiuka. 2-e vyd. Kyiv : Smoloskyp, 2006. $856 \mathrm{~s}$ :

2. Berestova A. A. Relihiina pretsedentnist u movi ukrainskoi prozy kintsia KhKh - pochatku KhKhI stolittia : dys. ... kand. filol. nauk : 10.02.01/ Kharkivskyi natsionalnyi pedahohichnyi universytet imeni H. S. Skovorody. Kharkiv, 2016. $212 \mathrm{~s}$.

3. Grishaeva L. I. Pretsedentnyie fenomenyi kak kulturnyie skrepyi (k tipologii pretsedentnyih fenomenov). Fenomen pretsedentnosti i preemstvennost kultur / pod obsch. red.: L. I. Grishaevoy, M. K. Popovoy, V. T. Titova. Voronezh : VGU, 2004. S. $15-46$. 
4. Gudkov D. B. Teoriya i praktika mezhkulturnoy kommunikatsii. Moskva : ITDGK “Gnozis", 2003. $288 \mathrm{~s}$.

5. Denisova G. V. V mire interteksta: yazyik, pamyat, perevod. Moskva : Azbukovnik, 2003. $298 \mathrm{~s}$.

6. Klieshchova O. Ye. Mova publitsystyky Ivana Bahrianoho : avtoref. dys. ... kand. filol. nauk : 10.02.01. Kyiv, 2003. $23 \mathrm{~s}$.

7. Koloiz Zh. V. Proekt ukrainskoho "Slovnyka pretsedentnykh fenomeniv". Filolohichni studii : Naukovyi visnyk Kryvorizkoho derzhavnoho pedahohichnoho universytetu. Kryvyi Rih : FOP Marynchenko S. V., 2017. Vyp. 16. S. 139-160.

8. Krasnyih V. V., Gudkov D. B., Zaharenko I. V., Bagaeva D. V. Kognitivnaya baza i pretsedentnyie fenomenyi v sisteme drugih edinits i v kommunikatsii. Vestnik Moskovskogo universiteta. Seriya 9 : Filologiya. 1997. № 3. S. 62-75.

9. Semenets O. P. Pretsedentnyiy tekst v yazyike gazetyi : dis. ... kand. filol. nauk : 10.02.01 / Rossiyskiy gosudarstvennyiy pedagogicheskiy universitet im. A. I. Gertsena. Sankt-Peterburg, 2004. 225 s.

10. Slyishkin G. G. Lingvokulturnyie kontseptyi i metakontseptyi: dis. ... d-ra filol. nauk : 10.02.19 / Volgogradskiy gosudarstvennyiy pedagogicheskiy universitet. Volgograd, 2004. 315 s.

11. Slyishkin G. G. Ot teksta k simvolu: lingvokulturnyie kontseptyi pretsedentnyih tekstov v soznanii i diskurse. Moskva : Akademiya, 2000. 128 s.

Стаття надійшла до редакиії 08.06.2018 p. Прийнята до друку 15.11. 2018 р. 